\title{
African Universities: Problems, COVID-19 \& Efforts
}

\section{Universidades Africanas: Problemas, COVID-19 \& Esfuerzos}

DOI: $10.46932 / \mathrm{sfjdv} 2 \mathrm{n} 2-011$

Received in: january 1 st, 2020

Accepted in: March 30th, 2020

\section{Carlos Rios-Campos}

Docente Investigador RENACYT. Universidad Nacional Toribio Rodríguez de Mendoza de Amazonas. Doctor en Gestión Universitaria. Bagua, Perú.

E-mail: carlos.rios@untrm.edu.pe

Jury Yesenia Aquino Trujillo

Docente universitaria. Maestría en Ingeniería de Sistemas. Universidad Católica Santo Toribio de Mogrovejo. Chiclayo, Perú.

\section{Antero Alexander Cabrera Torres}

Docente asociado. Licenciado en Estadística, Maestría en Educación y Doctorado en Administración de la Educación. Universidad Nacional de Frontera. Chiclayo, Perú.

\section{Janeth Leticia Mora Zapater}

Docente universitaria. Magister en Enseñanza de Inglés como Idioma Extranjero. Licenciada en Lengua Inglesa Especialización Lingüística y Literatura. Universidad Laica Vicente Rocafuerte de Guayaquil.

E-mail: jmoraz@ulvr.edu.ec

\section{Patricia Mercedes Tapia Macias}

Abogada. Magíster en Ciencias Internacionales y Diplomacia. Guayaquil, Ecuador.

E-mail:patty_tapia56@yahoo.com

\section{María Raquel Maxe Malca}

Docente universitaria y asesora de tesis de pregrado. Doctora en Educación. Maestría en Ingeniería de los Procesos Industriales. Ingeniera Química. Universidad César Vallejo. Chiclayo, Perú.

E-mail: maxer30@hotmail.com

Italo Maldonado Ramírez

Decano de la Facultad de Ingeniería de Sistemas y Mecánica Eléctrica. Doctor en Administracion de la Educación. Universidad Nacional Toribio Rodríguez de Mendoza de Amazonas. Bagua, Perú.

\section{Roberto Carlos Santa Cruz Acosta}

Director Departamento Académico de Ingeniería. Maestro en Ingeniería de Sistemas. Universidad Nacional Toribio Rodríguez de Mendoza de Amazonas. Bagua, Perú.

E-mail: roberto.santacruz@untrm.edu.pe

\begin{abstract}
It is necessary to know the state of the Universities in Latin America. The general objective was determine the situation of African Universities: Problems, COVID-19 \& Efforts. Methodology, in this research, 39 documents have been selected, carried out in the period 2016 - 2021; including: scientific articles, review articles and information from websites of recognized organizations. The keywords used in the searches
\end{abstract}


were: African universities, African higher education, African universities COVID-19. Results, Universities in Africa receive inadequate funding, while maintenance costs rise; the Covid-19 pandemic had already had an impact on normal university expenditure and in short, the vision is to create worldclass universities, based on African models and solutions. Conclusions, during the pandemic, African universities have closed their doors and due to the lack of technological resources and Internet access for students, classes cannot be taught properly.

Keywords: African universities, higher education, COVID-19.

\section{INTRODUCTION}

Africa is now facing a major demographical challenge. According to recent UN forecasts, the continent is expected to double its population by 2050, from 1 billion to nearly 2.4 billion inhabitants. Most importantly, half of that population will be less than 25 years old, which raises the urgent question of whether its economy has the capacity to absorb the millions of new arrivals that will soon flood its job market (AFD, 2019).

Yet the continent remains stubbornly inhospitable - politically, economically, and socially - to young people. The success of African governments' efforts to address this will be the single most important factor determining whether the continent prospers or suffers in the coming decades (UNDP, 2017).

Figure 1. Map of Africa

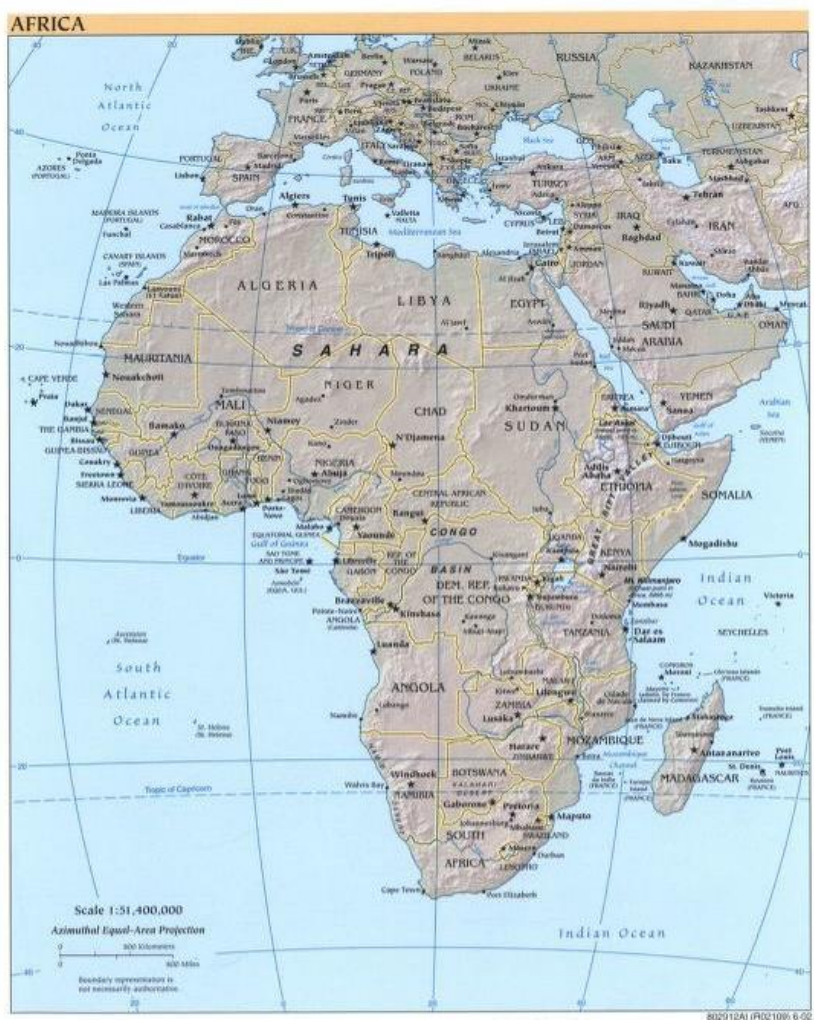

Source: United States Central Intelligence Agency (2002) 
From the early 2000s, a new discourse emerged, in Africa and the international donor community, that higher education was important for development in Africa. Within this 'zeitgeist' of converging interests, a range of agencies agreed that a different, collaborative approach to linking higher education to development was necessary (Cloete, Bunting \& van Schalkwyk, 2018).

A total of 13 African universities are featured in the QS World University Rankings® 2020, with the majority (eight) of these found in South Africa... The first six universities are all ranked in the 8011000 range* and are therefore joint eighth in Africa (Collier, 2020).

South Africa's 26 public universities are all members of Universities South Africa. They are distributed within all nine provinces of South Africa. Each province has at least one university, with Mpumalanga and the Northern Cape provinces having just acquired their own institutions during 2014/2015 (Universities South Africa, 2021).

Figure 2. Universities In South Africa

\begin{tabular}{|c|c|}
\hline Name of the university & Web \\
\hline Cape Peninsula University of Technology & https://www.cput.ac.za/ \\
\hline Central University of Technology, Free State & https://www.cut.ac.za/ \\
\hline Durban University of Technology & https://www.dut.ac.za/ \\
\hline Mangosuthu University of Technology & https://www.mut.ac.za/ \\
\hline Nelson Mandela University & https://www.mandela.ac.za/ \\
\hline North-West University & https://www.nwu.ac.za/ \\
\hline Rhodes University & https://www.ru.ac.za/ \\
\hline Sefako Makgatho Health Sciences University & https://www.smu.ac.za/ \\
\hline Sol Plaatje University & https://www.spu.ac.za/ \\
\hline Stellenbosch University & https://www.sun.ac.za/ \\
\hline Tshwane University of Technology & https://www.tut.ac.za/ \\
\hline University of Cape Town & https://www.uct.ac.za/ \\
\hline University of Fort Hare & https://www.ufh.ac.za/ \\
\hline University of Johannesburg & https://www.uj.ac.za/ \\
\hline University of KwaZulu-Natal & https://www.ukzn.ac.za/ \\
\hline University of Limpopo & https://www.ul.ac.za/ \\
\hline University of Mpumalanga & https://www.ump.ac.za/ \\
\hline University of Pretoria & https://www.up.ac.za/ \\
\hline University of South Africa & https://www.unisa.ac.za/ \\
\hline University of the Free State & https://www.ufs.ac.za/ \\
\hline University of the Western Cape & https://www.uwc.ac.za/ \\
\hline University of the Witwatersrand & https://www.wits.ac.za/ \\
\hline Vaal University of Technology & https://www.vut.ac.za/ \\
\hline University of Zululand & https://www.unizulu.ac.za/ \\
\hline Walter Sisulu University & https://www.wsu.ac.za/ \\
\hline
\end{tabular}

Source: Higher Education \& Training Republic of Soth Africa (2021). 
Figure 3. University Rankings

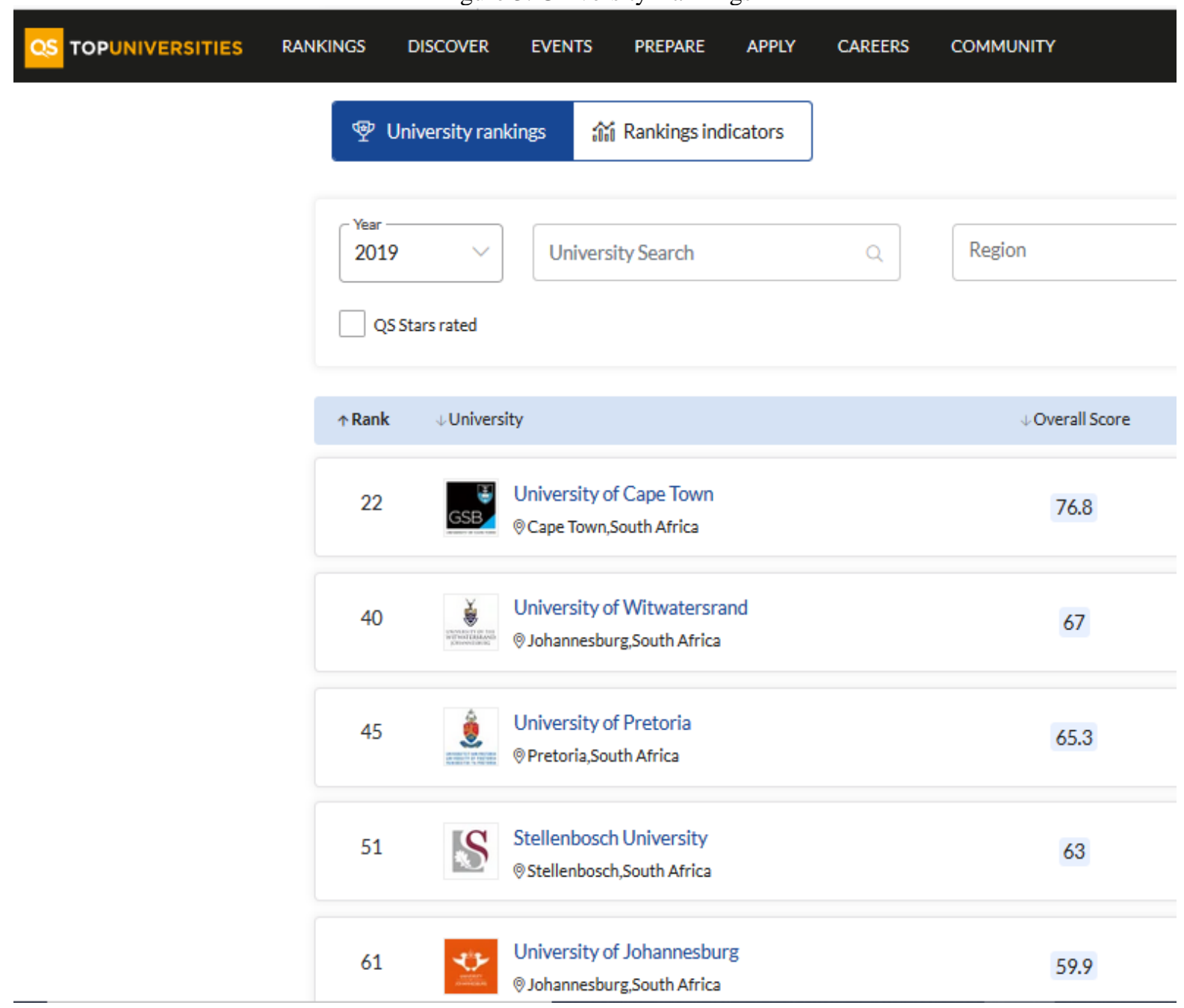

Source: Topuniversities (2019)

Research into the mechanisms for financing of higher education in sub-Saharan Africa which can deliver expanded access, quality and equity will depend and largely draw on a framework of the macroeconomic context, demographic shift, demand and supply, and the regulatory framework for delivering and managing sustainable quality higher education in the region (Oketch, M. (2016).

In the case of South Africa's 20 universities and 6 universities of technology, higher education institutions generate or receive slightly more revenue from student fees, donations and other sources (the orange line) than they do from government grants (the blue line). In 2019, total revenue amounted to just over R88 billion, with R42 billion from government grants and R46 billion from non-grant funding (Statistics South Africa, 2020).

Political, business, and cultural elites from around the world have a strong affinity for the United Kingdom (UK) education system. Nowhere is this truer than in West Africa, where some families in Nigeria and Ghana have a long tradition of sending their children to private boarding schools and universities in the UK (Page, 2021). 


\section{METHODOLOGY}

The research presents a qualitative-interpretative design, of a documentary type, which specified the selection procedure and the data recording (Barrero y Rosero, 2018).

In this research, 39 documents have been selected, carried out in the period 2016 - 2021; including: scientific articles, review articles and information from websites of recognized organizations. The keywords used in the searches were: African universities, African higher education, African universities COVID-19. For the selection of the documents, the following criteria were used: the year of publication, belonging to the research and being a reliable source. After reading each document, the data was entered into the bibliographic matrix, which is used to catalog the documents according to categories, which are presented in Figure 1.

Figure 1. Bibliographic matrix

\begin{tabular}{|l|l|l|l|}
\hline Name & Type & Objectives & Conclusions \\
\hline & & & \\
\hline
\end{tabular}

Source: Adapted from Barrero \& Rosero (2018).

\section{RESULTS}

\subsection{PROBLEMS}

Corporate organizational practices, commodification and commercialization of knowledge, dictated by market ethics, dominate university practices in Africa with negative impact on professional values, norms and beliefs (Cross \& Ndofirepi, 2017).

This report provides analyses of the \#FeesMustFall protests in nine universities...Over the years, historically black universities have been characterised by multiple and violent student protests, well before the \#FeesMustFall movement in 2015 and 2016 (Langa, Ndelu, Edwin \& Vilakazi, 2017).

Overall enrollments in higher education have more than doubled since the end of the apartheid system in South Africa in 1994, when a reported 495,000 students were enrolled in higher education. A significant part of enrollment gains occurred in distance education programs - 372,331 students, or about one third of the 969,155 students enrolled at public universities in 2014 , were studying in distance education mode (Macha \& Kadakia, 2017).

South Africa has 26 public universities with nearly one million students while 700000 students are registered at the more than 50 higher education training colleges (TVET colleges - Technical vocational education training). An additional 90000 students can be found at various private institutions (Tjønneland, 2017).

The findings revealed a lack of effective relationships between universities and USC to preserve communities' histories. Hence, the communities' archives are tools for teaching and scholarship. 
Relations between universities and USC are to be built on trust. Accountability and transparency are to be considered by both parties (Netshakhuma, 2019).

The mandatory phasing in of the Moodle learning environment within South African universities has met with a variety of uptake challenges... The study revealed that the top-down imposition of mandatory Moodle implementation was resisted by lecturers, hindering uptake, and maximum potential was difficult to measure (Mpungose, 2020).

The reason for this "student exodus" is that those who can afford it head abroad for their tertiary education. Why do they go? A survey done last year found that $71 \%$ of African students studying outside Africa thought a degree earned abroad represented a higher-level qualification than a degree at home (UNESCO, 2019).

In recent decades millions of young people like Mr Bahati have swelled the number of students in sub-Saharan Africa. Today $8 \mathrm{~m}$ are in tertiary education, a term that includes vocational colleges and universities (The Economist, 2019).

While South African scholarly attitudes and behaviour are certainly shaped by the institutional policy structures in which they are situated, they are also impacted by the social, departmental,and disciplinary norms and expectations, or "culture,"that defines their workspace and networks (Cox \& Trotter, 2019).

If this is the situation in the US, imagine the situation in Africa. As country after country announced lockdowns, universities emptied out. The majority of students are at home, most do not have access to laptops and in some cases, even to smartphones (The World Bank Group, 2021).

Universities in Africa receive inadequate funding, while maintenance costs rise. Plus, they face disruptions by strikes, sociopolitical unrest and challenges like the current coronavirus pandemic. For all of these reasons, African higher education institutions are forced to search for alternatives (UNICAF, 2021).

\section{COVID-19}

The Minister of Higher Education, Science and Innovation is consulting with Vice Chancellors of universities and colleges across the country and will soon be announcing measures in this regard," the statement said, adding those who have been in contact with the student will be quarantined (Isilow, 2020).

Covid-19 has paved the way for African universities to lead from the front on local issues whilst tackling global challenges head-on; ensured that the knowledge project supports a multiplicity of voices, methods and framings; and forged inclusive communities of scholars across the world (Osman, 2020). 
Since the announcement of the outbreak in January 2020, Nelson Mandela University has been exploring ways in which it can help fight the spread of the virus. Everyone is encouraged to take responsibility by educating yourself about the virus, and to heed all precautionary measures (Nelson Mandela University, 2020).

A UWC COVID-19 Advisory Team consisting of University management, officials and medical experts is closely monitoring and following recommendations from the National Institute for Communicable Diseases, the National Department of Health, the World Health Organization (WHO) and other official sources. In addition, the team, and other professional staff, have set in motion academic and business continuity plans in the event of an emergency (University of the Western Cape, 2021).

Nzimande said the Covid-19 pandemic had already had an impact on normal university expenditure, and substantial savings were realised with the postponement of a range of activities such as cancelled conferences and limited travel and accommodation.

(Maqhina, 2020)

\subsection{EFFORTS}

Just one year after its establishment, the African Research Universities Alliance (ARUA) is once again garnering attention for its effectiveness in connecting a diverse group of African Universities to global university networks. The alliance, made up of 15 institutions from eight African countries...(Carnegie Corporation of New York, 2016).

The African Research Universities Alliance (ARUA) is a network of universities from different countries and different historical backgrounds, but with a common vision. ARUA aims to enhance research and graduate training in member universities through a number of channels, including the setting up of Centres of Excellence (CoEs) to be hosted by member universities (ARUA, 2017).

The study reported that students at the two universities had similar perceptions of entrepreneurial intentions, and that students from Tshwane University of Technology are more likely to encourage other people to study entrepreneurship education than their Walter Sisulu University counterparts (Letsoalo \& Rankhumise, 2020).

In short, the vision is to create world-class universities, based on African models and solutions, which can help transform societies and nations and tackle the local and global challenges of today and tomorrow (Chipperfield, 2016).

Drawing on disruptive innovation theory and a review of mainstream literature on MOOCs adoption in American and African tertiary sectors, this study argues that behind the MOOC rhetoric of disrupting and democratizing higher education lies the projection of top academic brands on the 
marketing pedestal, financial piggybacking on the hype and politics of academic exclusion (Rambe \& Moeti, 2017).

The network of higher education institutions in the US and SA was founded in 2018 to strengthen South Africa's higher education sector, and this grant will allow UP and the University of Venda, working with Rutgers University-Newark, to increase the number of students from SA and the US engaged in exchanges, collaborative research and other partnerships (Boje, 2020).

The role of leadership in universities is a good starting point from which to deepen an understanding of decolonisation. The narratives of the participants illuminate some of the complexities, tensions and challenges that leadership continue to face in South Africa (Du Plessis, 2021).

However, the university cannot fully decolonise if society remains in colonial mode. The university must play a dual, concurrent role of decolonising itself and informing the societal decoloniality project (Chikoko, 2021).

South Africa offers the highest standard of university education in Africa. It is home to 23 public universities offering both academic and vocational study, including many rating highly in the QS World University Rankings (Cambridge International, 2021).

South Africa is leading the top 200 best universities in Africa in 2020, according to Unirank... On the list, the University of Pretoria, University of Cape Town, University of the Witwatersrand, University of Johannesburg and University of KwaZulu-Natal, all South African based universities have been ranked in the top five (Buningwire, 2020).

Schools and organisations such as Bridge2Rwanda (Rwanda), Barwaaqo University (Somaliland), Nova Pioneer Schools for Innovators and Leaders (Kenya/South Africa), Makomborero (Zimbabwe), African Leadership Academy (South Africa) and CIYOTA/COBURWAS (Uganda/DRC) are examples of organisations that have created strong international partnerships...(Acholonu \& Njie, 2020).

\section{CONCLUSIONS}

With the end of apartheid, the number of students in South Africa increased. African universities are having trouble raising funds and serving the growing number of students. During the pandemic, African universities have closed their doors and due to the lack of technological resources and Internet access for students, classes cannot be taught properly. Many of these students, due to the aforementioned difficulties and financial limitations, have had to withdraw from the university. African universities make joint efforts to improve it, such as the African Research Universities Alliance (ARUA). South Africa offers high standards of university education in Africa, some of them stand out in the QS World University Rankings. 


\section{BIBLIOGRAPHIC REFERENCES}

Acholonu, I. \& Njie, S. (2020). African students' access to higher education is a priority for the continent's development. Retrieved from https://blogs.lse.ac.uk/africaatlse/2020/11/20/african-students-accesshigher-education-priority-for-development/

AFD (2019). By 2050, More Than Half of Africa's Population Will be under 25 Years Old. Retrieved from https://www.afd.fr/en/actualites/2050-more-half-africas-population-will-be-under-25-years-old

ARUA (2017). ARUA Concept. Retrieved from https://arua.org.za/about/

Barrero, A. \& Rosero, A. (2018). Estado del Arte sobre Concepciones de la Diversidad en el Contexto Escolar Infantil. Revista Latinoamericana de Educación Inclusiva, 2018, 12(1), 39-55 https://doi.org/10.4067/S0718-73782018000100004

Boje, V. (2020). University of Pretoria Benefits from Huge U.S. Grant (Pretoria News). Retrieved from https://za.usembassy.gov/up-benefits-from-huge-u-s-grant-pretoria-news/

Buningwire (2020). Africa's Best Universities 2020: South Africa Leads Continental Rankings. Retrieved from https://www.ktpress.rw/2020/07/africas-best-universities-2020-south-africa-leads-continentalrankings/

Cambridge International (2021). South Africa. Retrieved from https://www.cambridgeinternational.org/programmes-and-qualifications/recognition-andacceptance/country/southafrica/

Carnegie Corporation of New York, 2016). African Research Universities Alliance. Creating opportunities for universities across the continent. Retrieved from https://www.carnegie.org/topics/topicarticles/african-academics/african-research-university-alliance-creating-opportunities-universitiesacross-continent/

Chikoko (2021). Re-visiting the decolonising of South African higher education question: a systematic literature review. Vol. 35 No. 1 (2021). https://doi.org/10.20853/35-1-4420

Chipperfield, C. (2016). Universities are at the heart of Africa's economic rise. Retrieved from https://www.britishcouncil.org/voices-magazine/universities-are-heart-africas-economic-rise

Cloete, N., Bunting, I. \& van Schalkwyk, F. (2018). Research Universities in Africa. Retrieved from https://www.africanminds.co.za/research-universities-in-africa/

Collier, S. (2020). Top Universities in Africa. Retrieved from https://www.qschina.cn/en/universityrankings-articles/world-university-rankings/top-universities-africa

Cox, G. \& Trotter, H. (2016). Institutional Culture and OER Policy: How Structure, Culture, and Agency Mediate OER Policy Potential in South African Universities. International Review of Research in Open and Distributed Learning, 17 (5), 147-164. https://doi.org/10.19173/irrodl.v17i5.2523

Cross, M. \& Ndofirepi, E. (2017). Knowledge and Change in African Universities. Retrieved from https://www.springer.com/la/book/9789463008457 
Du Plessis (2021). Decolonisation of education in South Africa: challenges to decolonise the university curriculum. South African Journal of Higher Education. Vol. 35 No. 1 (2021). https://doi.org/10.20853/35-1-4426

Higher Education \& Training Republic of Soth Africa (2021). Universities In South Africa. Retrieved from https://www.dhet.gov.za/SitePages/UniversitiesinSA.aspx

Isilow, H. (2020). South Africa orders schools closed as COVID-19 spreads. Retrieved from https://www.aa.com.tr/en/africa/south-africa-orders-schools-closed-as-covid-19-spreads/1767271

Langa, M., Ndelu, S., Edwin, Y. \& Vilakazi, M. (2017). \#Hashtag: An Analysis of the \#FeesMustFall Movement at South African Universities. Retrieved from https://www.africaportal.org/publications/hashtag-an-analysis-of-the-feesmustfall-movement-at-southafrican-universities/

Letsoalo, M.E., \& Rankhumise, E.M. (2020). Students' entrepreneurial intentions at two South African universities. Journal of Entrepreneurship Education, 23(1)

Macha, W. \& Kadakia, A. (2017). Education in South Africa. Retrieved from https://wenr.wes.org/2017/05/education-south-africa

Maqhina, M. (2020). Covid-19 financial impact on SA universities stands at over R3.8bn. Retrieved from https://www.iol.co.za/news/politics/covid-19-financial-impact-on-sa-universities-stands-at-over-r38bnf41d76f5-27d0-4071-9c6e-f725cfe0e861

Mpungose, C.B B (2020). Beyond limits: Lecturers' reflections on Moodle uptake in South African universities. Educ Inf Technol 25, 5033-5052. https://doi.org/10.1007/s10639-020-10190-8

Nelson Mandela University (2020). It is in your hands the fight against COVID-19. Retrieved from https://www.mandela.ac.za/News-and-Events/Coronavirus-Information

Netshakhuma, N.S. (2019). Analysis of South African universities and communities archives, Global Knowledge, Memory and Communication, Vol. 68 No. 8/9, pp. 635-651. https://doi.org/10.1108/GKMC02-2019-0015

Oketch, M. (2016). Financing higher education in sub-Saharan Africa: some reflections and implications for sustainable development. High Educ 72, 525-539. https://doi.org/10.1007/s10734-016-0044-6

Osman, R. (2020). Higher education reconsidered. Retrieved from https://www.wits.ac.za/covid19/covid19-news/latest/higher-education-reconsidered.html

Page, M. (2021). West African Elites' Spending on UK Schools and Universities: A Closer Look. Retrieved from https://carnegieendowment.org/2021/01/28/west-african-elites-spending-on-uk-schoolsand-universities-closer-look-pub-83736

Rambe, P. \& Moeti, M. (2017). Disrupting and democratising higher education provision or entrenching academic elitism: towards a model of MOOCs adoption at African universities. Education Tech Research Dev 65, 631-651. https://doi.org/10.1007/s11423-016-9500-3 
Statistics South Africa (2020). Universities depend more on government for funding. Retrieved from http://www.statssa.gov.za/?p=13719

The Economist (2019). Tertiary education in Africa. A booming population is putting strain on Africa's universities. Retrieved from https://www.economist.com/middle-east-and-africa/2019/08/10/a-boomingpopulation-is-putting-strain-on-africas-universities

The World Bank Group (2021). Digital Skills and Technologies: How African Universities are Straightening the Steep Learning Curve. Retrieved from https://www.worldbank.org/en/news/feature/2020/06/13/digital-skills-and-technologies-how-africanuniversities-are-straightening-the-steep-learning-curve

Tjønneland, E. (2017). Crisis at South Africa's universities - what are the implications for future cooperation with Norway?. Retrieved from https://www.cmi.no/publications/6180-crisis-at-south-africasuniversities-what-are-the

Topuniversities (2019). BRICS Discover the top universities from Brazil, Russia, India, China and South Africa with the QS BRICS University Rankings 2019. Retrieved from https://www.topuniversities.com/university-rankings/brics-rankings/2019

UNESCO (2019). Scholarly success of African universities: common contributing factors / The Conversation. Retrieved from https://www.iesalc.unesco.org/2019/09/05/scholarly-success-of-africanuniversities-common-contributing-factors/

UNICAF (2021). Why african universities should offer an online option. The challenges faced by African universities. Retrieved from https://www.unicaf.org/why-african-universities-should-offer-an-onlineoption/

United States Central Intelligence Agency. (2002) Africa. [Washington, D.C.: Central Intelligence Agency] [Map] Retrieved from the Library of Congress, https://www.loc.gov/item/2004634080/.

Universities South Africa (2021). Public Universities in South Africa. Retrieved from https://www.usaf.ac.za/public-universities-in-south-africa/

University of the Western Cape (2021). Protocol. Retrieved from https://www.uwc.ac.za/news-andannouncements/covid-19-portal/protocol

UNDP (2017). Africa's defining challenge. Retrieved from https://www.africa.undp.org/content/rba/en/home/blog/2017/8/7/africa_defining_challenge.html 